\title{
Role of Human Resource Practices and Corporate Entrepreneurship: Mediation of Transformational Leadership and Product Innovation Performance
}

\author{
Masoodul Hassan \\ Department of commerce, \\ Bahauddin Zakariya University, Multan, Pakistan \\ Email: masoodulhassan@bzu.edu.pk \\ Asia Abbas \\ Department of commerce, \\ Bahauddin Zakariya University, Multan, Pakistan \\ Email: asiaabbas45@gmail.com \\ Faryal Batool (Corresponding author) \\ Department of commerce, \\ Bahauddin Zakariya University, Multan, Pakistan \\ Email:faryalbatool11@gmail.com \\ Khalil Ahmad \\ Institute of Business Administration Sukkur \\ Email: khalilchanna@iba-suk.edu.pk
}

\begin{abstract}
Leadership is considered as an important factor that influences product innovation performance. Contemporary global economies continuously strive to foster innovation and improvisation in their production is the demand of today's global economy that organizations continuously bring innovation and improve their products. The purpose of present research is to find out that how transformational leadership linked to product innovation. Moreover, the study hypothesized that corporate entrepreneurship and human resource practices mediate the relationship of transformational leadership and product innovation performance. Present research is based on quantitative research design and 150 survey questionnaires were employed to collect data from Textile sector of Pakistan. To analyze data, WarPLS was used. The findings confirmed the hypotheses that the study contributes toward the theory of leadership by uncovering the impact of human resource practices in innovation. Moreover, the findings of our study show that transformational leadership positively influence product innovation performance. It implies that managers should improve their leadership style in order to encourage employees to take part in innovative activities. Other variables such as learning orientation and supervisory commitment can be investigated in future studies.
\end{abstract}

Keywords: Product Innovation Performance, Human Resource Practices, Transformational Leadership, Corporate Entrepreneurship

\section{Introduction}

Leadership plays crucial role in shaping the future and fortune of a business. It is a process in which an individual motivates other persons to get their goals. Organizational Performance is affected by different Leadership styles. Transformational Leadership has influenced the organizational performance more than the transactional leadership. 
Among various leadership styles, transformational leadership is suggested as more effective over others. Transformational leaders provide the clear vision and define the organizational goals. Previous studies disclosed that Leadership is an important factor which impact organizational innovation. The present research is based on the transformational leadership theory, which states that transformational leadership is able to obtain high level performance by setting challenging goals to motivate leaders themselves and other members in the group. These leaders bring innovative and creative ideas towards analytical and managerial activities. Therefore, many research studies found that transformational leaders affect product innovation performance because they provide foundation for building organizational strategy and through product innovation performance, organization can obtain competitive advantage.

Organizations need to adopt innovative approach in product design in order to get competitiveness. Product innovation can be described as "new product and service which is introduced to satisfy customer needs". Although many researches have been undertaken to examine the connection between transformational leadership and product innovation performance; still there is insufficient empirical evidence on the specific modes which influence the relationship of transformational leadership and product innovation performance.

As discussed above, it enforces that transformational Leaders boost the innovative thinking of their subordinates. Transformational leadership supports the concept of corporate entrepreneurship. Corporate entrepreneurship consists of three elements; self-renewal, new product development and business venturing. These elements may influence product innovation performance. Many research studies found that the dimensions of corporate entrepreneurship such as risk taking, innovativeness and proactiveness are positively related with performance. Successful organizations focus on corporate entrepreneurship in order to achieve competitive advantage. Based on these arguments, it can be assumed that corporate entrepreneurship positively impacts firm performance. Therefore, continuous product developments can be considered as the result of high level corporate entrepreneurship.

Putting HR practices in the context and equation of above discussion, firms may use HR practices such as staffing, employees training, appraisals and rewards to involve employees in the process of innovation. There is positive impact of human resource practices on employees' behavior, attitude and performance. In order to develop new products, firms require creative ideas from their employees. To this end, firms need employees who have ability to take risk and effectively deal with unpredictability. The employees as human resources to organizations can be defined as the greatest asset of an organization. When firm uses creative abilities as selection criteria, employees express more innovative behaviors. Training assists employees to disclose knowledge and performance appraisal boosts employees' motivation to take part in creative actions. Therefore; the arguments suggest that firms may improve their potential to introduce new product and services with HR practices.

Human resource practices are expected to influence corporate entrepreneurship. Sustained regeneration is the form of corporate entrepreneurship in which firms involve in regeneration of products and services. It is found in previous research that there is significant positive relationship between corporate entrepreneurship and Product Innovation Performance. The current research makes contribution in existing literature in two major domains. First, by investigating the mediating effect of corporate entrepreneurship on the relationship of transformational leadership and product innovation performance. Second, given that extant literature provide little awareness on the importance of human resource practices. Current research focuses on this particular dimension and aimed to determine the role of human resource practices as mediator to the relationship of transformational leadership and product innovation performance.

Therefore, the objective of the present research is mainly to find out whether the relationship of transformational leadership and product innovation performance exists in Pakistan's context.

\section{Background and Hypotheses Development:}

Leadership is a critical factor that influences product innovation. Different People perceive the meaning of leadership differently. Leadership is a process of influencing others towards some kind of desired outcome. This depicts that leadership style varies from situation to situation. 
Transformational Leadership was coined by Burns (1978), Bass and extended by Avolio (1994). According to them, transformational leaders have four characteristics: Idealized Influence, Inspirational Motivation Intellectual Stimulation, and Individualized Consideration. By intellectual stimulation, transformational leaders influence employee's creativity. These leaders allow their followers to take actions independently and take risk that enhance innovation.

Through inspirational motivation, transformational leaders share a persuasive goal with their followers and motivate them to achieve it. Burns found idealized influence as charisma. Inspirational motivation and idealized influence both are used to form Charismatic-Inspirational Leadership. Through idealized influence, transformational leader inspires their followers. It has been confirmed in previous studies that individual performance is affected by idealized influence. By individualized consideration, transformational leaders individually treat their subordinates and maintain close relationship with them so that they can recognize their needs and goals.

Table 1: Dimensions of Transformational Leadership

\begin{tabular}{|c|c|c|}
\hline Dimensions & Description & Conclusion \\
\hline Intellectual Stimulation(IS) & $\begin{array}{l}\text { Leaders encourage innovation } \\
\text { and include followers in } \\
\text { addressing problems and } \\
\text { finding solution }\end{array}$ & $\begin{array}{l}\text { Transformational leaders influence } \\
\text { employee's creativity }\end{array}$ \\
\hline Idealized Influence(II) & Leader is a role model & $\begin{array}{l}\text { Employee's performance is improved } \\
\text { by idealized influence }\end{array}$ \\
\hline Inspirational Motivation(IM) & $\begin{array}{l}\text { Transformational Leader } \\
\text { explain vision to all } \\
\text { organization members }\end{array}$ & $\begin{array}{l}\text { Vision and Passion are the part of } \\
\text { leader's personality }\end{array}$ \\
\hline Individualized Consideration(IC) & Leader act like a mentor & $\begin{array}{l}\text { Give importance to the needs of their } \\
\text { employees }\end{array}$ \\
\hline
\end{tabular}

Source: (Bass and Avolio, 2004)

(ii) The role of Product Innovation Performance

Innovation is considered as a vital factor for firm's stability and expansion in today's enterprising era which is owing to globalization and resultant compressed product life cycle. It is expected from organizations to continuously innovate and improve their products and services. Therefore, management scholars and practitioners are taking interest in Product Innovation and leadership is a critical factor that affects Product Innovation. According to Hambrick, leaders may impact product innovation because they take decisions about the organizational strategy Transformational leaders support innovative behavior of followers which lead to product innovation performance. Therefore, there is need to determine the relationship of transformational leadership and product innovation performance.

H1: Transformational leadership is positively related with Product Innovation Performance.

\section{(iii) The role of Corporate Entrepreneurship}

The idea of corporate entrepreneurship is given by Pinchot (1985) who termed it as 'intrapreneur'. Intrapreneurs are defined as the persons who innovate for the organization where they work. On the other hand, entrepreneurs innovate for themselves. Corporate Entrepreneurship refers to as "Formal or informal activities to create new businesses in established firms through product and process innovations and market developments". This concept is related to innovative activities in firms. It is the requirement of today's dynamic environment that traditional firms implement entrepreneurial strategies in order to get success. 
Many researchers found that firm's performance can be enhanced by corporate entrepreneurship. Through corporate entrepreneurship, we bring new ideas and focus on innovation. In Transformational leadership, leaders encourage their subordinates to provide new ideas and encourage entrepreneurial activities in firms. These leaders build up confidence and self-efficacy in their followers so that they can perform innovative work. They also provoked their employees to handle problems in new ways. In this way, corporate entrepreneurship can lead to competitive advantage. Moreover, diversified products and markets can be the result of corporate entrepreneurship. According to Karagozoglu and Brown, a firm is categorized as entrepreneurial only if it is engaged in Product Innovation. Therefore, it can be proposed that Corporate Entrepreneurship mediates the relationship between Transformational Leadership and Product Innovation Performance.

H2: Corporate Entrepreneurship mediates the relationship of Transformational Leadership and Product Innovation Performance.

\section{(iv) The role of Human Resource Practices}

Human Resource Practices are the main drivers through which organizations can enhance the abilities of their employees in order to obtain organizational goals. Three main parts of human resource practices are: (1) People flow such as staffing and training (2) Employment relations such as job design (3) Appraisal and rewards. It has been suggested in previous studies that high performance human resource practices motivate employees to contribute in innovative ideas. Through strategic HR practices such as staffing, training and performance appraisal, Firms may encourage and engage their employees in innovative activities. There is positive impact of human resource practices on employees' satisfaction and organizational productivity. On the basis of these arguments, it can be hypothesized that transformational leaders may use human resource practices to modify the behavior of their subordinates to introduce new products and services. Therefore, it is important to examine the mediating impact of HR practices on the relationship of transformational leadership and product innovation performance.

H3: There is mediating role of Human Resource Practices on the relationship between Transformational Leadership and Product Innovation Performance.

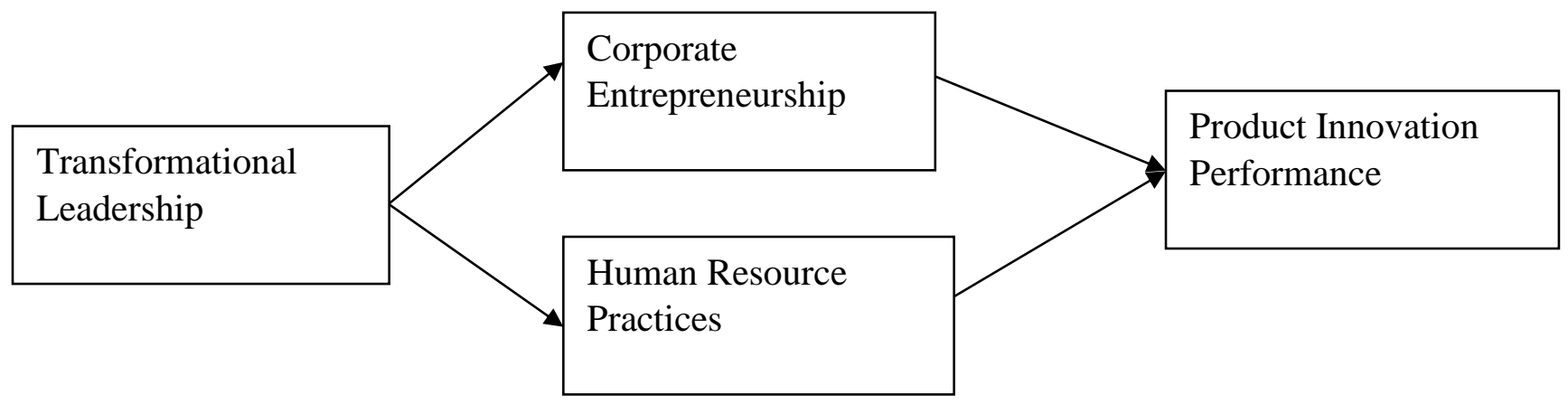

\section{Methodology}

Quantitative research design was used in this study. Data was collected by using survey questionnaire from Textile sector of Pakistan. Five Point Likert Scale which ranged from 1=strongly disagree to 5=strongly agree was used. Language of questionnaire was English. WarPLS were used to analyze the data.

\section{(i) Sampling and Data collection Procedure}

Textile sector is one of the most significant sectors of Pakistan. It is the backbone of Pakistan's economy. In this study, data was collected from textile sector. Total population of textile Sector is unknown. By using online sample size calculator, sample size was calculated which was equal to 384 . We visited different firms randomly and met 
with their CEOs. We assured CEOs that the data obtained would be confidential. Before distributing survey questionnaire, a brief introduction of our research was given. Survey questionnaire were distributed to 384 employees working in textile firms both public and private sector. Total 175 employees returned filled questionnaire. From these filled questionnaires, 25 responses were improperly filled and discarded for future process. Hence, the response rate was 39\% and the average organizational tenure was 6 years. Average age of respondents was 30-35 years old.

\section{(ii) Measures}

A 6-item scale which was originally developed by Bass, Avolio\& Jung (1999) is used to measure Transformational Leadership. To measure corporate entrepreneurship, a scale having 6 items developed by Hinkin (1998) is used. This study adopted 6 item-scales to measure human resource practices developed by Narang (2013). Likewise, product innovation performance is measured through 6 items scale originally developed by Luca and Atuahene-Gima (2007).

\section{Analysis Results and Discussion}

The objective of present research is to study the relationship among transformational leadership, human resource practices ,corporate entrepreneurshhip and product innovation performance. We propose that there is positive relationship between transformational leadership and product innovation performance . Moreover, there is mediating impact of corporate entrepreneurship and human resource practices on the relationship of transformational leadership and product innovation performance.

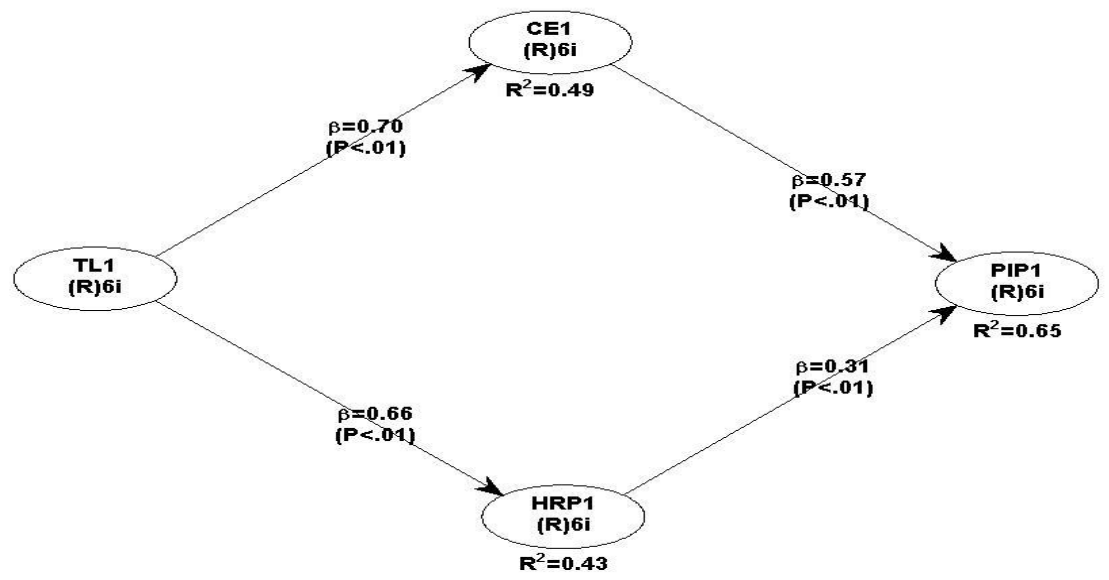

Table 2: Results 


\begin{tabular}{|l|l|l|l|l|}
\hline $\begin{array}{l}\text { Statistical } \\
\text { Result }\end{array}$ & $\begin{array}{l}\text { Transformational } \\
\text { Leadership }\end{array}$ & $\begin{array}{l}\text { Corporate } \\
\text { Entrepreneurship }\end{array}$ & $\begin{array}{l}\text { Human } \\
\text { Resource } \\
\text { Practices }\end{array}$ & $\begin{array}{l}\text { Product } \\
\text { Innovation } \\
\text { Performance }\end{array}$ \\
\hline R square & & 0.49 & 0.43 & 0.65 \\
\hline P value & $<.01$ & $<.01$ & $<.01$ & $<.01$ \\
\hline Beta & 0.70 & 0.57 & 0.66 & 0.31 \\
\hline
\end{tabular}

\section{Indirect Effects}

\begin{tabular}{|l|l|l|l|l|}
\hline & CE & HRP & PIP & TL \\
\hline CE & 1.000 & & & \\
\hline HRP & & 1.000 & & \\
\hline PIP & & & 1.000 & \\
\hline TL & & & 0.549 & 1.000 \\
\hline
\end{tabular}

Total Effects

\begin{tabular}{|l|l|l|l|l|}
\hline & CE & HRP & PIP & TL \\
\hline CE & 1.000 & & 0.574 & \\
\hline HRP & & 1.000 & 0.257 & \\
\hline PIP & & & 1.000 & \\
\hline TL & 0.670 & 0.638 & 0.549 & 1.000 \\
\hline
\end{tabular}

After collecting the data, the next step was to carefully analyze the data for accuracy. WarPLS is used to analyze the data. By using WarPLS, the R square of corporate entrepreneurship is 0.49. It is also known as coefficient of determination. $\mathrm{R}$ square is a statistical measure which shows the correlation. $\mathrm{R}$ square shows variance of model. Similarly R square of human resource practices and product innovation performance is 0.43 and 0.65 . P value of all variables is less than .01 which is significant. Beta of transformational leadership (TL) is 0.70, corporate entrepreneurship (CE) 0.57, human resource practices (HRP) 0.66 and product innovation performance (PIP) is 0.31.Beta is also known as regression coefficient.

\section{Analysis of reliability and validity}

Partial least squares approach for structural equation modeling is also used in this study to analyze the data as opposed to LISREL or other methods. Because PLS allows us to analyze the smaller sample sizes than LISREL. We can easily present the results of Smart PLS through graph and this graph provides sufficient information to reader regarding the measurements of the model. PLS was proposed by Wold (1982). In order to assess the reliability and validity of our data, we measure composite reliability and convergent validity.

Table 3: Average Variance Extracted, Composite Reliability and Cronbach's alpha

\begin{tabular}{|l|l|l|l|}
\hline Variables & Average Variance Extracted & $\begin{array}{l}\text { Composite } \\
\text { Reliability }\end{array}$ & Cronbach's Alpha \\
\hline CE & 0.517 & 0.810 & 0.690 \\
\hline
\end{tabular}




\begin{tabular}{|l|l|l|l|}
\hline HRP & 0.518 & 0.810 & 0.690 \\
\hline PIP & 0.504 & 0.835 & 0.751 \\
\hline TL & 0.518 & 0.842 & 0.764 \\
\hline
\end{tabular}

\section{Convergent Validity}

We analyze convergent validity by measuring average variance extracted, composite reliability and Cronbach's alpha. Table 4 summarizes the results. The concept of Average Variance Extracted (AVE) was originally given by Fornell and Larcker (1981). Average Variance Extracted (AVE) is a method that evaluates the convergent Validity of a given construct .AVE should be higher than 0.5. As shown in Table 4,AVE of all variables is greater than 0.5.

Composite reliability shows the inter-item consistency. The required minimum value is 0.7 . Results show that the composite reliability of all variables is above 0.8 which means that all variables are highly consistent. Cronbach's Alpha measures the internal consistency. For Cronbach's alpha, values from 0.6 to 0.7 are required. Result reveals that all variables meet this requirement.

Table 4: Path Coefficient

\begin{tabular}{|l|l|l|l|l|}
\hline Variable & CE & HRP & PIP & TL \\
\hline CE & & & 0.574 & \\
\hline HRP & & & 0.257 & \\
\hline PIP & & & & \\
\hline TL & 0.670 & 0.638 & & \\
\hline
\end{tabular}

Table 4 summarizes the results of Path Coefficient. The Path Coefficients measured by PLS present the sign of relationships. As mentioned in Table 4, corporate entrepreneurship has path coefficient of 0.574 with the relationship of product innovation performance. Path coefficient of human resource practices is 0.257 with respect to product innovation performance. Similarly, transformational leadership has path coefficient with respect to corporate entrepreneurship and human resource practices is 0.670 and 0.638 .

Table 5: R square

\begin{tabular}{|l|l|}
\hline Variables & R square \\
\hline CE & 0.449 \\
\hline HRP & 0.407 \\
\hline PIP & 0.554 \\
\hline
\end{tabular}

$\mathrm{R}$ square is also called coefficient of determination. It is the percentage of variance. $\mathrm{R}$ square of corporate entrepreneurship is 0.449 , human resource practices are 0.407 and $\mathrm{R}$ square of product innovation performance is 0.554 which is significant.

\section{Discussion}

Following the study of Aaron which suggested that Leadership is linked with organizational and employees' performance; past research studies also proved that leadership is a vital factor which affects product innovation performance. Findings confirmed the hypothesis that transformational leadership is positively related with product innovation performance $(\beta=0.70, \quad p<.01)$. Previous studies also claimed positive relationship between transformational leadership and product innovation performance $(\beta=.16, p<.05)$. This implies that transformational leaders influence employees' creativity and encourage their employees to participate in entrepreneurial activities.

Secondly, results also support this hypothesis $(\beta=0.57, \mathrm{p}=<.01)$.Consistent with the studies of Chen et al.,(2014), which also support that corporate entrepreneurship mediates the relationship between Transformational Leadership and Product Innovation Performance $(\beta=.01)$. While the authors of this study noticed that the values of our study are strongly greater $(\beta=0.57)$ than the values of Chen et al., $(\beta=.01)$. It implies that corporate entrepreneurship leads to numerous product development and strongly mediates the relationship of Transformational Leadership and 
Product Innovation Performance. Moreover, the study proposed (H3) that Human Resource Practices mediate the relationship between Transformational Leadership and Product Innovation Performance.

The hypothesis was also supported by the results $(\beta=0.66, \mathrm{p}=<.01)$. This implies that HR practices such as staffing, job design, and training and appraisal system boost the firms' potential to introduce new products and services. This study contributes to the literature by highlighting the role of Human Resource Practices in innovation and suggests that leaders should concentrate human resource practices so that they can improve product innovation performance.

\section{Theoretical Implications}

Current study has many theoretical implications. This study informs the readers that human resource practices such as staffing, training, job design, appraisal and rewards lead toward innovation. The current study advances the theory of leadership by uncovering the role of human resource practices in innovation. Firms need creative abilities of their employees in producing new products and exploit new opportunities. Human resource practices transform the behavior of employees to obtain strategic goals. Firms may use human resource practices to engage employees in entrepreneurial activities.

\section{Practical Implications}

This study also has practical implications for managers and CEO's of the firms. Findings of our study show that transformational leadership has positive impact on product innovation performance. It implies that managers should improve their leadership style in order to encourage employees to take part in innovative activities. Moreover, results revealed that corporate entrepreneurship mediates the relationship of transformational leadership and product innovation performance. These results encourage CEO's to enhance entrepreneurial practices in the firm to support product innovation. This paper also suggests that human resource practices have positive impact on employee's motivation to bring innovative ideas. Hence, firms should focus on human resource practices to improve the execution of transformational leadership.

\section{Future Recommendations}

Each study has some limitations. These limitations can be considered for further enhancement in literature. The present research is focused on Punjab province. Future research can be conducted in other provinces and in other countries as well in order to widespread the results of this study to other economies and culture. Another limitation of this study is that in this study one method is used. Future Research can be conducted by using both quantitative and qualitative method. Same framework can be investigated by using other variables such as Learning Orientation, Supervisory Commitment.

\section{Conclusion}

Leaders play an important role in implementing innovation. As highlighted in the literature, leadership style is a critical factor that influences innovation and creativity. The findings from the current study suggest that product innovation performance can be enhanced by adopting transformational Leadership. Transformational leaders are not only creative but they are also willing to take risk which is the dimension of Corporate Entrepreneurship. The findings also reveal the positive impact of human resource practices on the relationship of transformational leadership and product innovation performance.

\section{References}

Barry, D., \& Meisiek, S. (2010). The art of leadership and its fine art shadow. Leadership, 6(3), 331-349.

Bass, B. M., \& Avolio, B. J. (2005). MLQ: Multifactor leadership questionnaire: Mind Garden.

Chahrour, M., et al. (2008). MeCP2, a key contributor to neurological disease, activates and represses transcription, Science, 320(5880), 1224-1229.

Chully, A. A., \& Sandhya, N. (2012). Impact of Transformational Leadership Style: A Review of Global Studies in the Past 5 years, International Journal of Science and Research, 3(8), 791-798

Damanpour, F. (1991). Organizational innovation: A meta-analysis of effects of determinants and moderators, Academy of management journal, 34(3), 555-590. 
De-Jong, J. P., \& Den-Hartog, D. N. (2007). How leaders influence employees' innovative behaviour, European Journal of innovation management, 10(1), 41-64.

Hater, J. J., \& Bass, B. M. (1988). Superiors' evaluations and subordinates' perceptions of transformational and transactional leadership, TheJournal of Applied Psychology, 73 (4), 695-702.

Lumpkin, G. T., \& Dess G. G. (2001). Linking two dimensions of entrepreneurial orientation to firm performance: The moderating role of environment and industry life cycle, Journal of business venturing, 16(5), 429-451.

Pinchot III, G. (1985). Intrapreneuring: Why you don't have to leave the corporation to become an entrepreneur, University of Illinois at Urbana-Champaign's Academy for Entrepreneurial Leadership Historical

Research Reference in Entrepreneurship.

Song, M., \& Noh. J. (2006). Best New Product Development and Management Practices in the Korean Hightech Industry, Industrial Marketing Management, 35(3), 262-78.

Twomey, D. F., \& Harris, D. L. (2000). From strategy to corporate outcomes: Aligning human resource management systems with entrepreneurial intent, International Journal of Competitiveness, 10(3 and 4), 43-55.

Yukl, G. (2012). Leadership: What is it."Cases in leadership: Thousand Oaks, CA: Sage.

Jung, D., Chow, C. \& Wu, A. (2003). The role of transformational leadership in enhancing organizational innovation: Hypotheses and some preliminary findings, The Leadership Quarterly, 14(4-5), 525-544. 